\title{
ZOOLOGÍA
}

\section{SPECIES RICHNESS, DENSITIES AND BIOMASS OF NINE PRIMATE COMMUNITIES IN EASTERN COLOMBIA}

\author{
Thomas R. Defler*
}

\begin{abstract}
Defler T. R.: Species richness, densities and biomass of nine primate communities in eastern Colombia. Rev. Acad. Colomb. Cienc. 37 (143): 253-262, 2013. ISSN 0370-3908.

This is a preliminary comparison of nine primate communities from Colombian Llanos and Amazonia, including three communities in Llanos gallery forest and six communities from the Amazon basin. Total primate biomass in the extreme eastern Colombian Amazon is considerably lower than reported at other sites at longitudes of $5^{\circ}-8^{\circ}$ south of the Amazon-Solimões in Brazil and Peru. Primate richness at the Colombian sites (up to 10 sympatric species) was below that found at other sites in Brazil and Peru (up to 14 sympatric species), where the highest neotropical species richness seems to be situated. Although primate species richness was reduced in the Colombian gallery forest sites, biomass per community surpassed terra firme moist eastern forest sites, but was comparable to biomass of the only black-water igapó forest in this study.
\end{abstract}

Key words. primate communities, primate densities, primate biomass, primate species richness, Colombian Amazon.

\section{RESUMEN}

Este estudio presenta una comparación preliminar de nueve comunidades de primates en Colombia que incluye tres comunidades en bosque de galería en los Llanos Orientales y seis comunidades en la cuenca amazónica. La biomasa de primates en la Amazonia colombiana fue considerablemente más baja en comparación con las biomasas reportadas en otros estudios en longitudes entre $5^{\circ}-8^{\circ}$ al sur del río Amazonas-Solimões en Brasil y Perú. La riqueza de primates en los sitios colombianos (hasta 10 especies simpátricas), también fue más baja en comparación con otros sitios localizados en Brasil y Perú (hasta 14 especies simpátricas), donde la riqueza más alta de primates neotropicales parece estar concentrada. Aunque la riqueza de especies de primates se redujo en los bosques de galería en Colombia, la biomasa por comunidad sobrepasó los sitios de bosques húmedos del oriente de terra firme, pero es comparable con la biomasa reportada en el único sitio localizado en bosque inundable por aguas negras (igapó) de este estudio.

Palabras clave. Comunidades de primates, densidades de primates, biomasa de primates, Amazonia colombiana.

* Departamento de Biología, Universidad Nacional de Colombia, Bogotá, Colombia. E-mail: thomasdefler@gmail.com 


\section{Introduction}

Data on the diversity and density of neotropical primates has multiplied in the past few years, providing a clearer idea of the great variability of primate communities in Amazonia and elsewhere. Peres \& Palacios (2007) compare 101 neotropical sites having data for mid-sized to large vertebrate species, including primates. Moreover, Peres (2008) compares soil fertility, including 96 Amazonian forest sites. That analysis suggests that soil fertility had a significant positive effect on primate biomass, while hunting pressure has a negative effect on the primate community. More recent reports show great variability from species poor and low-density sites to communities with 14 syntopic species and high densities (Endo et al., 2009).

Since primates are often considered flagship-species and are used to evaluate the health of forest ecosystems, as well as providing a high percentage $(24 \%-40 \%)$ of frugivore biomass, their importance to tropical forests has often been underlined (Dietz et al., 1994; Defler, 2010; Palacios \& Peres, 2005; Maldonado, 2012). This makes them one of the most suitable candidates for regional-scale ecological comparisons, as they represent one of the most important biomass components of arboreal vertebrate assemblages (Emmons, 1984; Peres, 2008). Primates' ecological roles in seed dispersion, as well as prey and as predators are increasingly appreciated for their impact on diversity (Howe \& Smallwood, 1982; Garber \& Lambert, 1998; Stevenson et al., 2002; Stevenson \& Pilar Medina, 2003; Chapman \& Russo, 2007). Additionally, these charismatic animals are effectively used as flagship species for habitat conservation (Dietz, et al. 1994; Maldonado, 2012).

In this study I calculate and compare primate diversities in eastern Colombian Amazonian forest with that of some sites in the Colombian Llanos. I also compare eastern Colombian Amazonian sites (over $3200 \mathrm{~mm}$ precipitation) with some other selected Amazonian non-Colombian sites. Various studies show correlations of increases of primate species richness and plant diversity up to about $2,500 \mathrm{~mm}$ of annual precipitation and a decrease in rates of primate and plant species richness inversely correlated with higher precipitation (Peres \& Janson, 1999; Gentry, 1982, 1989; Kay et al. 1997). Eastern Colombian Amazonian forests typically show annual precipitation above about $3200 \mathrm{~mm}$.

A priority of this study is to characterise primate communities unaffected by human activities to provide baseline data for eastern Colombia. Information on intact primate communities is especially important because the alterations caused by hunting and habitat disturbance make it difficult to draw meaningful ecological conclusions, since some comparisons are distorted by human interference (Voss \& Emmons, 1996; Peres, 1993, 2008). In this study I attempt to show why primate biomass and species richness is so much lower throughout the Eastern Colombian Amazon where precipitation reaches levels considerably over $3,000 \mathrm{~mm}$ as compared to other high biomass and species rich sites that are especially found south of the Amazon river, although in Colombia more elevated primate biomass is reported elsewhere. Comparisons in this study with the Colombian Llanos also underline fundamental differences from eastern Colombia, especially with species like Alouatta seniculus and Cebus apella.

\section{Methods}

\section{Study sites}

I censused three sites from the eastern Colombian llanos and six Amazonian sites in southern Colombia (Fig. 1). Data across these locations were obtained between the years 1977 -2008 , with the object of making a comprehensive, comparative study of primate density in eastern Colombia. Nine sites (1-9) were located in areas with minimal or no human intervention. "Igapó forest" is used as a term in the sense of Pires \& Prance (1985) for blackwater and clearwater rivers, which is the case for the Apaporis river, which has origins of both blackwater and clearwater affluents (Hoorn et al., 2010). Although the Apaporis river has been considered a blackwater river by many (Goulding et al. 2003; Correa, 2008; Davis, 1996; Umaña et al. 2011) it does not show all the characteristics of igapó from the central Amazon, especially the highly sandy soils of the flooded forests, especially because of its mixed origins, underlined by Junk \& Furch (1985). The Apaporis has its origins in a southern extension of the Llanos Orientales and in its lower parts, including the Lago Taraira, the waters are sometimes blackwater and sometimes turbid and muddy.

In the Caparú surveys (sites 4-5), two different habitats: (upland forest and seasonally flooded igapó forest) were censused. Both forest types were used by the same primate population. In the Purité river surveys, sites $7 \& 8$ were separated by about $2 \mathrm{~km}$, although they were on opposite sides of the river. Sites $8 \& 9$ were separated by about $8.3 \mathrm{~km}$ and were on the same side of the river. All the Amazonian sites were located in a zone of very high precipitation above 3,200 $\mathrm{mm}$.

Following Peres (1997), these non-hunted sites (1-9) showed no evidence of hunting or rubber tree (Hevea spp.) exploitation. The extremely isolated Puré and Purité Rivers are both well over $100 \mathrm{~km}$ upriver from their respective river mouths. The only possibility of significant primate hunting would 


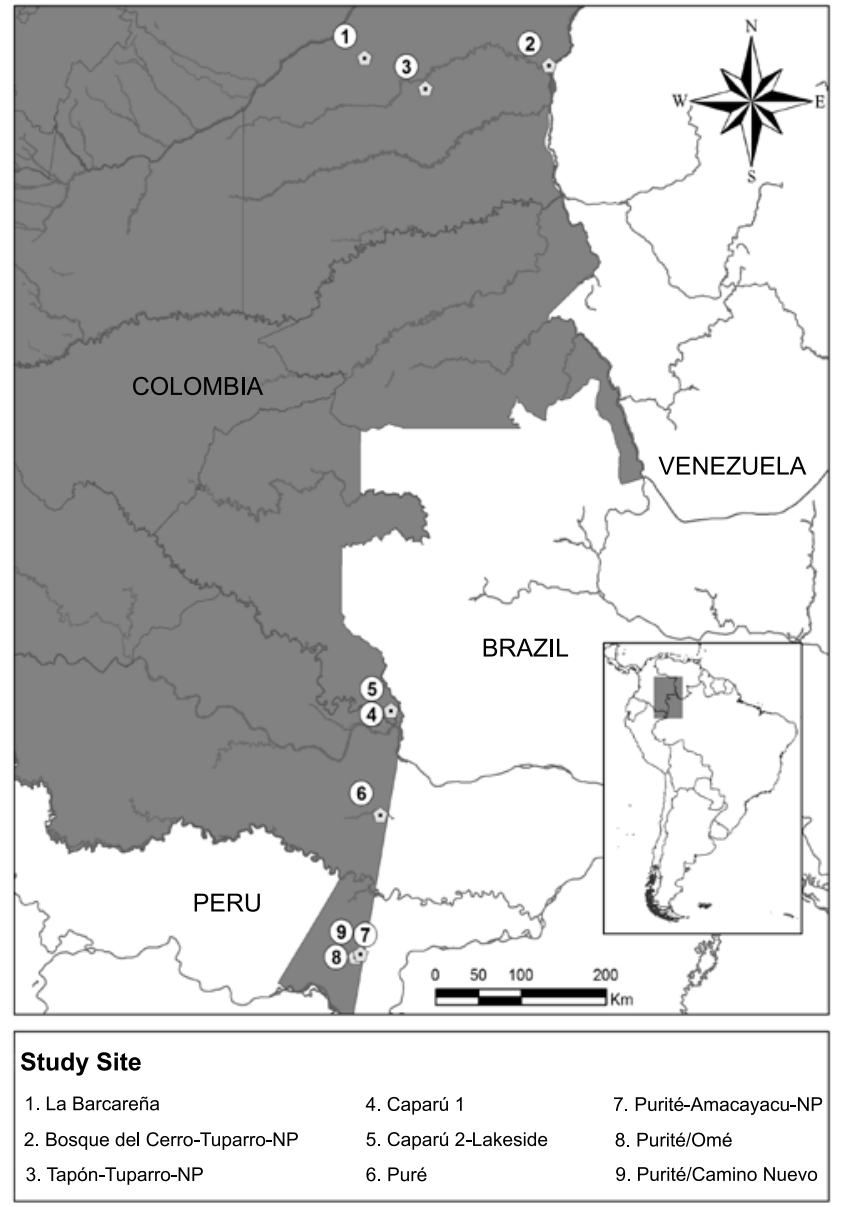

Figure 1. Map of the 13 study sites located in the Colombian Llanos and Colombian Amazon

have been over 30 years ago, when primates were used as bait in commercial hunting of spotted cats (Defler, 1983). Earliest censuses followed NRC (1981) and were later conducted according to Peres $(1993,1999)$ and Buckland $\boldsymbol{e t}$ al. (2001) using standardised line-transect census protocols for all census sites studied in recent years.

\section{Census techniques}

\section{Gallery forests.}

Densities at El Tuparro (2-3) were determined by direct count, since the main research included many hours habituating and observing the primates of those clearly-defined forests (Defler \& Pintor, 1985). At La Barcareña I walked a previously cut $5 \mathrm{~km}$ transect and measured perpendicular distances by first measuring the distance to the first observed animal(s) and the angle between the observation distance and the transect, in order to convert to perpendicular distance to the group. Perpendicular distance to first animal observed were measured by tape. Density was calculated using ( $\mathrm{D}=$ $\mathrm{ND} / \mathrm{L} 2(\mathrm{ESW})$ ) where $\mathrm{D}=$ group density, $\mathrm{ND}=$ number of sightings per species, $\mathrm{L}=$ cumulative transect length walked at each site, $\mathrm{ESW}=$ effective strip width or largest perpendicular distance observed for each species excluding outliers. There is a controversy whether detection distance should be to the center of the group or to the first animal, but in practice one most easily focuses on the first animal detected, since the group center is not easily identified. For detection widths I drew a frequency distribution of the various distances where groups had been observed, then truncated it at the point where observations fell off; multiplying this by two yielded a detection width for calculating densities as follows :

\section{Amazonian sites}

For Caparú (4-5) I used a five $\mathrm{km}$ transect perpendicular to lake's edge for the no. 4 site and a $10 \mathrm{~km}$ canoe transect (equals $5 \mathrm{~km}$ census for both sides of the lake route) for the igapó habitat. The line transect censuses were carried out over 2.5 years, twice a month, for a total distance census of $476 \mathrm{~km}$ including $212 \mathrm{~km}$ of censuses by canoe in igapó and $264 \mathrm{~km}$ of censuses in terra firme forests. Group size used for each detection event of Lagothrix was 24 individuals rather than a direct count, as 24 was the known count of the two groups most commonly detected along the transect route and no local group was less than 20 . This was considered to provide a more accurate estimate as long as there was no danger of counting subgroups as separate groups. The census data were analysed using DISTANCE 4.0 software when an adequate sample was available. Low densities required the use of detection distances for the analysis (as described above), since there were not enough observations for the use of DISTANCE. Some species were never detected during censuses though their presence was confirmed. For example, during inland transect censuses at Caparú Cacajao melanocephalus was never detected, though densities have been reported for this site using other techniques (Defler, 2001). Caparu's data set for Lagothrix was analysed using both methods and compared to a previous direct count (Defler, 1983).

Robust estimates may not be feasible for species that are rarely observed. Nevertheless, estimates are presented here for most species where adequate data have been collected. In order to improve the reliability of the estimates by avoiding outliers, perpendicular distances were truncated at the point where detection events fell off and this distance was doubled for the analysis. To estimate biomass, I multiplied the mean body mass per $\mathrm{km}^{2}$ for each species by $80 \%$ of average adult weights, following Peres (1997). 
Soil characteristics were determined for sites no. 1 and 4 -9 via four widely separated collections per site and values were averaged. Physico-chemical characteristics were determined at the soil laboratory of the Instituto Augustín Codazzi in Bogotá for micronutrients. Methods used at the Laboratorio Nacional de Suelos (IGAC) can be reviewed at the following link (http://www.igac.gov.co/wps/wcm/connect/ dd516280464b0aab8a70cb525e257f7f/LISTADO+DE+ME
TODOS+EMPLEADOS+EN+EL+LABORATORIO+NAC IONAL+DE+SUELOS.pdf?MOD=AJPERES).

\section{Results and Discussion}

Primate species richness in nine different communities (Table 3) varied from 2-10 species and estimated primate community biomass ranged from 87 along the Puré river to 387

Table 1. Characteristics of the nine sampling sites included in this study

\begin{tabular}{|c|c|c|c|c|c|c|c|}
\hline Census Site & $\begin{array}{l}\text { Forest } \\
\text { Type }^{1}\end{array}$ & $\begin{array}{l}\text { Hunting } \\
\text { pressure }\end{array}$ & No. of Species ${ }^{2}$ & Census Period & $\begin{array}{l}\text { Census } \\
\text { Effort }\end{array}$ & $\begin{array}{r}\text { Density } \\
\text { (ind } / \mathbf{k m}^{3} \text { ) }\end{array}$ & $\begin{array}{r}\text { Biomasa } \\
\left(\mathrm{kg} / \mathrm{km}^{2}\right) \\
\end{array}$ \\
\hline $\begin{array}{l}\text { 1. La Barcareña } \\
5^{\circ} 24^{\prime} 46^{\prime} \mathrm{N}-69^{\circ} 47^{\prime} 44^{\prime \prime} \mathrm{W}\end{array}$ & GF & None & 2 & March-1995 & 50 & 114 & 387 \\
\hline $\begin{array}{l}\text { 2. Bosque del Cerro-Tuparro-NP } \\
5^{\circ} 20^{\prime} 20.9^{\prime \prime} \mathrm{N}-67^{\circ} 50^{\prime} 43.5^{\prime \prime} \mathrm{W}\end{array}$ & GF & None & 3 & Jan-June-1977 & 67 & 66 & 190 \\
\hline $\begin{array}{l}\text { 3. Tapón-Tuparro-NP } \\
5^{\circ} 06^{\prime} 33.8^{\prime \prime} \mathrm{N}-69^{\circ} 08^{\prime} 58^{\prime \prime} \mathrm{W}\end{array}$ & GF & None & 4 & Aug-Dec-1977 & 56 & 77 & 370 \\
\hline $\begin{array}{l}\text { 4. Caparú } 1 \\
1^{\circ} 04^{\prime} 19.4^{\prime \prime S}-69^{\circ} 30^{\prime} 56.6^{\prime \prime} \mathrm{W}\end{array}$ & OTF & None & 8 & 1984-1987 & 264 & 48.2 & 133 \\
\hline $\begin{array}{l}\text { 5. Caparú 2-Lakeside } \\
1^{\circ} 05^{\prime} 02^{\prime \prime} \mathrm{S}-69^{\circ} 30^{\prime} 53.24^{\prime} \mathrm{W}\end{array}$ & Igapó & None & 8 & 1984-1987 & 212 & 97.1 & 215 \\
\hline $\begin{array}{l}\text { 6. Puré } \\
2^{\circ} 07^{\prime} 16.2^{\prime \prime S}-69^{\circ} 37^{\prime} 31.2^{\prime \prime} \mathrm{W}\end{array}$ & OTF & None & 10 & Nov - Dec-1999 & 50 & 47.9 & 87 \\
\hline $\begin{array}{l}\text { 7. Purité-Amacayacu-NP } \\
3^{\circ} 32^{\prime} 0.2^{\prime \prime} \mathrm{S}-69^{\circ} 54^{\prime} 16.3^{\prime \prime} \mathrm{W} \\
\end{array}$ & OTF & None & 9 & $2000-2001$ & 321 & 61 & 114 \\
\hline $\begin{array}{l}\text { 8. Purité/Omé } \\
3^{\circ} 32^{\prime} 09.8^{\prime} \mathrm{S}-69^{\circ} 53^{\prime} 27.2 .6^{\prime} \mathrm{W}\end{array}$ & OTF & None & 9 & $2000-2002$ & 370 & 66.1 & 161 \\
\hline $\begin{array}{l}\text { 9. Purité/Camino Nuevo } \\
3^{\circ} 30^{\prime} 7.92 ” S-69^{\circ} 50^{\prime} 8.85^{\prime} \mathrm{W}\end{array}$ & OTF & None & 9 & $2002-2003$ & 220 & 61.2 & 118 \\
\hline
\end{tabular}

1 Forest Type: GF: Gallery Forest-Llanos; OTF: Oligotrophic terra firme forest adjacent to black or clear water sources; Igapó: seasonally flooded forest by black water.

$2 \quad$ Number of primate species including Aotus spp.

3 Density and biomass of diurnal primates only

$4 \quad$ NP: National Park;

$5 \quad$ SANP: Southern Amacayacu National Park

Table 2. Soil properties from seven census sites, compared to high primate biomass site along the Duda river, Meta

$$
\text { (mEq/100g) }
$$

\begin{tabular}{|l|c|c|c|c|c|c|c|c|c|c|c|}
\hline & \%Sand & \%Silt & \%Clay & PH & Al & $\mathbf{C a}$ & $\mathbf{M g}$ & $\mathbf{K}$ & $\mathbf{N a}$ & $\begin{array}{c}\mathbf{P} \\
\left(\mathbf{P}_{\mathbf{2}} \mathbf{\mathbf { O } _ { \mathbf { 5 } }}\right)\end{array}$ & $\mathbf{C E C}$ \\
\hline Barcareña & 37 & 43 & 20.0 & 3.93 & 3.35 & 0.16 & 0.30 & 0.33 & 0.06 & 1.6 & 4.20 \\
\hline Caparú1 & 40 & 39.5 & 20.5 & 4.2 & 3.35 & 0.20 & 0.20 & 0.12 & 0.06 & 0.1 & 3.93 \\
\hline Caparú2 & 15 & 18 & 67.0 & 4.9 & 9.6 & 0.20 & 0.20 & 0.15 & 0.10 & 0.2 & 10.25 \\
\hline Puré & 45 & 36 & 19.0 & 3.6 & 4.73 & 0.26 & 0.20 & 0.20 & 0.02 & 0.3 & 5.40 \\
\hline Purité-Amacayacu NP & 75 & 17 & 7.5 & 3.45 & 2.45 & 0.13 & 0.11 & 0.10 & 0.02 & 0.3 & 2.80 \\
\hline Purité-Omé & 51 & 23.3 & 26.0 & 3.53 & 5.15 & 0.22 & 0.25 & 0.19 & 0.02 & 0.5 & 5.83 \\
\hline Purité-Camino Nuevo & 34 & 36.6 & 39.3 & 3.52 & 8.26 & 0.13 & 0.20 & 0.18 & 0.04 & 0.3 & 8.82 \\
\hline Duda river* & - & - & - & 5.0 & - & 13.5 & 8.45 & 15.7 & 23.5 & 1.5 & - \\
\hline
\end{tabular}

$\mathrm{CEC}=$ catión exchange capacity

$\mathrm{P}=$ parts per million

*Hirabuki \& Izawa, 1990 
Table 3. Primate community censuses in eastern Colombia expressed as number of groups observed / $10 \mathrm{~km}$ of census trail (SR); number of individuals $/ \mathrm{km}^{2}$ (D); kilograms of biomass $/ \mathrm{km}^{2}$ (B); figures in brackets correspond to direct count.

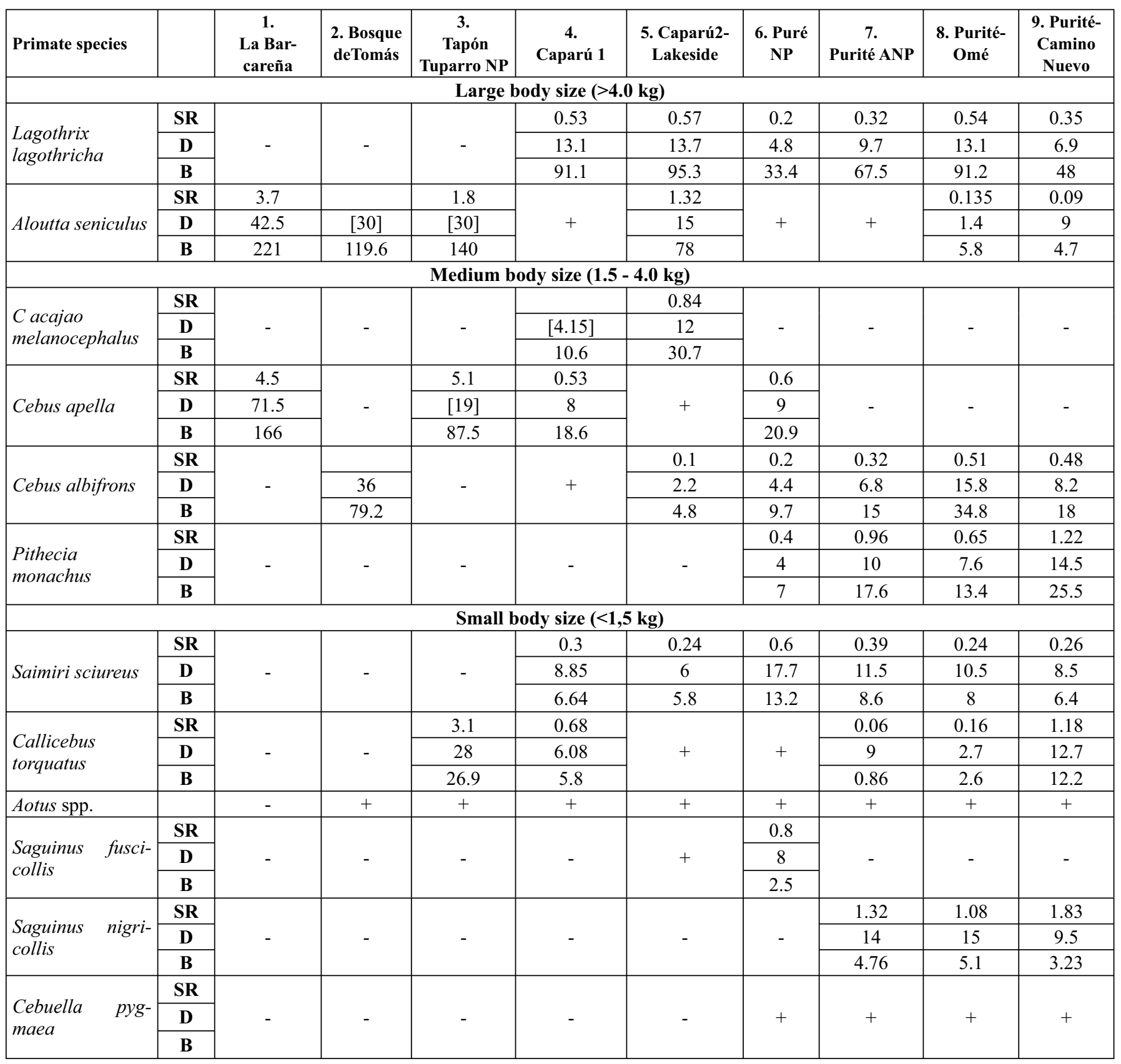

Symbols: (-) The species does not occur; (+) The species is present but was not detected during census.

$\mathrm{kg} / \mathrm{km}^{2}$ in a pristine gallery forest (Table 1 ). Densities of total individuals of all species varied from $47.9-114$ individuals/ $\mathrm{km}^{2}$. These are modest numbers when compared to sites having high densities and many individuals, such as seen in studies by Janson \& Emmons, 1990; Puertas \& Bodmer, 1993; Stevenson, 1996; Peres, 1997; Haugaasen \& Peres,
2005; Endo et al., 2008 and others. The Colombian llanos gallery forest sites 1-3 had the highest biomass estimates registered in this study, while they had the lowest species richness (2, 3, 4 species) mostly due to Alouatta and Cebus species (either C. apella or C. albifrons); but site 2, a gallery forest, also exhibited one of the two highest densities of $\mathrm{Ca}$ - 
llicebus torquatus calculated. In Colombia the highest densities and biomass known is found on the Duda river (Meta) in piedmont forest where some soil characteristics are known (Stevenson, 1996; Table 2).

Eastern Colombian Amazon sites in this study had much less primate biomass than the Llanos sites or the Duda river, except for the seasonable floodable igapó forest site at Caparú (no. 5). In fact, many un-hunted Amazonian sites in eastern Colombia had extremely low primate biomass and density of individuals (sites $4,6,7,8,9$ ). The data broadly agree with density and biomass data collected by Palacios and Peres for the same region (Palacios \& Peres, 2005; Table 4).

Soil characteristics for inland Amazonian sites in eastern Colombia (Table 2) showed extremely low fertility, including very low values for calcium, phosphorus, nitrogen and potassium, elements necessary for plant growth and probably at least partially explains the low biomass (Jordan, 1985; Hirabuki \& Izawa 1990; Peres, 2008). Low phosphorus levels especially contrasted highly and significantly with high phosphorus and high biomass levels measured at La Barcareña and at the Duda river piedmont forest site in the western Amazon (Table 2; Hirabuki \& Izawa, 1990). Very high rainfall (from $3200 \mathrm{~mm}$ in the south to $3950 \mathrm{~mm}$ ) in Caparú in this part of eastern Colombia has washed soils causing low nutrient availability at all sites in this part of the Colombian Amazon.

The exception is the seasonally flooded igapó forest at Caparú, which nevertheless supports high primate biomass, especially during highwater in April-July. Here one must assume that the yearly influx of nutrients supports a high seasonal density of frugivorous primate species due to very high seasonal fruit and leaf production at that time (Figure 2a,b).

\section{Comments on selected species}

In Caparú I obtained three different densities for Lagothrix: 5.5 individuals $/ \mathrm{km}^{2}$ from the direct count method (Defler, 1989); 11 individuals $/ \mathrm{km}^{2}$ using line transects, analysed using as described above [see Defler, 1989]; and 13.1 individuals $/ \mathrm{km}^{2}$ using the same data base analysed with DISTANCE (Defler, 2003). Palacios \& Peres (2005) censused the same primate population obtaining 6.6 individuals $/ \mathrm{km}^{2}$ using DISTANCE; this was closest to my direct count of 5.5 individuals $/ \mathrm{km}^{2}$. These divergent densities present a difficult interpretive problem that could be related to different methods. I conducted line transect census year round with an equal monthly effort whereas the study carried out by Palacios $\&$ Peres (2005) was conducted in November-December, a period of low resource availability when primate and other animal species often are obliged to concentrate on just a few key
Table 4. Characteristics of the 26 Amazonian primate communities compared with the 9 sites presented in this study

\begin{tabular}{|c|c|c|c|}
\hline Study site & $\begin{array}{r}\text { No. of } \\
\text { species }\end{array}$ & $\begin{array}{c}\text { Density } \\
\text { (ind//km²) }\end{array}$ & $\begin{array}{r}\text { Biomass } \\
\left(\mathbf{k g} / \mathbf{k m}^{2}\right)\end{array}$ \\
\hline \multicolumn{4}{|c|}{ Terra firme forest } \\
\hline La Barcareña & 2 & 114 & 387 \\
\hline Cerro de EI Tuparro & 3 & 66 & 190 \\
\hline Tapón El Tuparro & 4 & 77 & 370 \\
\hline Caparú1 & 8 & 48.2 & 133 \\
\hline Puré & 10 & 47.9 & 87 \\
\hline Purité-Amacayacu & 9 & 61 & 114 \\
\hline Purité-Omé & 9 & 66.1 & 161 \\
\hline Purité-Camino Nuevo & 9 & 61.2 & 118 \\
\hline Caparú1-Colombia & 8 & 61.9 & 175.7 \\
\hline Ayo'- Colombia & 10 & 86.9 & 169.5 \\
\hline Pintadillo-Colombia & 10 & 37.4 & 88.9 \\
\hline Duda river ${ }^{2}$-Colombia & 7 & 130.7 & 497.3 \\
\hline Porongaba $^{3}$, Brazil & 12 & 209 & 158 \\
\hline Sobra $^{3}$, Brazil & 11 & 174 & 117 \\
\hline Kaxinawá Reserve ${ }^{3}$, Brazil & 12 & 145 & 173 \\
\hline Condor $^{3}$, Brazil & 11 & 194 & 274 \\
\hline Penedo $^{3}$, Brazil & 10 & 129 & 118 \\
\hline Altamira $^{3}$, Brazil & 12 & 227 & 463 \\
\hline Barro VermelhoI ${ }^{3}$, Brazil $^{2}$ & 13 & 165 & 261 \\
\hline Fortuna $^{3}$, Brazil & 14 & 216 & 297 \\
\hline Riozinho $^{3}$, Brazil & 14 & 157 & 225 \\
\hline Igarapé Jaraquí ${ }^{3}$, Brazil & 13 & 137 & 131 \\
\hline Vira Volta ${ }^{3}$, Brazil & 13 & 182 & 282 \\
\hline Vai Quem Quer³, Brazil & 11 & 124 & 176 \\
\hline Urucu River ${ }^{4}$, Brazil & 13 & 146 & 381 \\
\hline Yavarí River ${ }^{5}$, Perú & 14 & - & 420 \\
\hline Cocha Cashu, Manu, Peru $^{6}$ & 14 & 287 & 655 \\
\hline \multicolumn{4}{|c|}{$\begin{array}{ll}\text { Varzea forest } \\
\end{array}$} \\
\hline Caparú2 & 8 & 97.1 & 215 \\
\hline Sacado $^{3}$, Brazil & 4 & 126 & 245 \\
\hline Nova Empresa ${ }^{3}$, Brazil & 6 & 185 & 410 \\
\hline Boa Esperança ${ }^{3}$, Brazil & 5 & 355 & 953 \\
\hline Barro Vermelho $\mathrm{II}^{3}$, Brazil & 7 & 213 & 361 \\
\hline Lago da Fortuna ${ }^{3}$, Brazil & 7 & 358 & 627 \\
\hline Lago Mamiraua $^{3}$, Brazil & 3 & 270 & 429 \\
\hline Lago Tejú3 ${ }^{3}$ Brazil & 4 & 175 & 352 \\
\hline Cajuana Island $^{3}$, Brazil & 6 & 120 & 389 \\
\hline
\end{tabular}

Data source: ${ }^{1}$ Palacios and Peres [2005]; ${ }^{2}$ Stevenson [1996]; ${ }^{3}$ Peres

[1997]; ${ }^{4}$ Peres [1993]; ${ }^{5}$ Puertas and Bodmer [1993].

plant species necessitating the exploitation of highly patchy resources in a very irregular fashion (Terborgh, 1983). This may have skewed the results obtained by Palacios \& Peres (2005) in comparison with my more evenly distributed data collection, nevertheless their results of 6.6 individuals $/ \mathrm{km}^{2}$ 


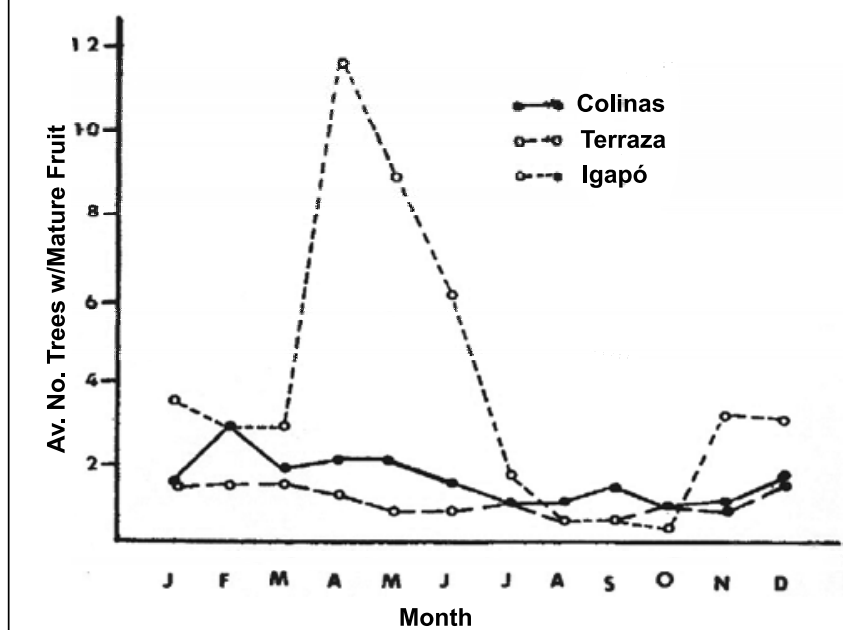

Fig. 2a. Seasonal variation in the availability of mature fruit crops in three habitats at the Estación Biológica Caparú (Defler \& Defler, 1996).

and my results of 5.5 individuals $/ \mathrm{km}^{2}$ calculated by direct count suggest that these low densities may be most accurate.

Because we knew the group size of the Lagothrix troops that were most commonly detected, we used 24 individuals to characterise each observation rather than the count of animals visible per detection. Peres (1999) argues that the use of average size for a species analysis may actually inflate the calculation, as subgroups may be counted as groups. In our case the data do not suggest that it was possible to have counted two subgroups, merely because observations were detected very far apart and any one observation represented the entire group. The difference between the putative direct count calculation of 5.5 individuals $/ \mathrm{km}^{2}$ and the DISTANCE calculation of 13.1 individuals $/ \mathrm{km}^{2}$ may illustrate the difficulty of making a direct count of animals based upon supposed recognition of groups in closed canopy rainforest or may illustrate inflated results for the DISTANCE calculation. In this paper we report calculations of Lagothrix at Caparú varying from 5.5 individuals $/ \mathrm{km}^{2}$ to 13.1 individuals $/ \mathrm{km}^{2}$.

Densities of Alouatta at almost all Amazonian sites are very low, at sites 4, 6-10 they were too low to calculate density using DISTANCE. At site 5 in an igapó forest, biomass and densities of Alouatta were the highest of all of the Amazonian sites, in agreement with other studies (Haugaasen \& Peres, 2005; Peres, 1993, 1997). In contrast, in the llanos sites 1,2,3 Alouatta is a major component of primate biomass. Increase in Alouatta densities towards the north in Colombia and extremely high densities in Guarico state, Venezuela suggest that optimal habitat for Alouatta is the ecotone or edge

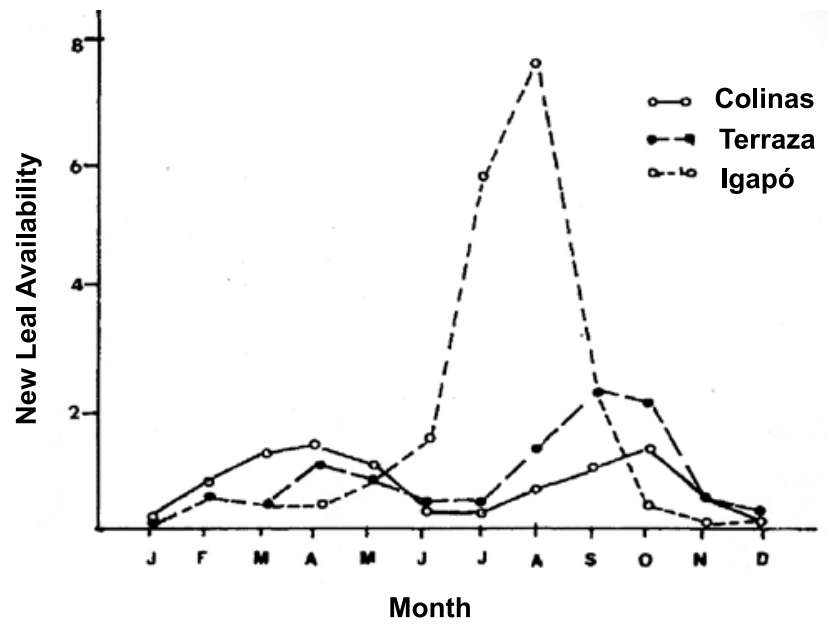

Fig. 2b. Seasonal variation in the availability of new leaves in three habitats at the Estación Biolóbica Caparú

(Defler \& Defler, 1996). habitat surrounded by savanna and not in closed-canopy forest (Crockett \& Eisenberg, 1987; Table 5). Habitat in flooded forest at Caparú produces extremely large pulses of new leaves and fruits, compared to other local terra firme habitats and as reported before in Defler \& Defler, (1996); (Figure $2 \mathrm{a} \& 2 \mathrm{~b}$ ). This preferred ecotone habitat explains the almost universal presence of Alouatta along river and lake edges and the very low densities or absence away from this habitat.

Table 5. Various densities of Alouatta seniculus, increasing towards northwards (in Colombia) towards the center of the Venezuelan llanos, suggest elucidation of preferred habitat for this species.

Census Site (s) Individuals $/ \mathbf{k m}^{2}$

\begin{tabular}{|c|c|}
\hline $\begin{array}{l}\text { Omé-río Purité (Defler, this study) } \\
\text { terra firme }\end{array}$ & 1.8 \\
\hline $\begin{array}{l}\text { Sur del Vaupés (Palacios \& Rodrí- } \\
\text { quez, 2001) igapó }\end{array}$ & 4 \\
\hline $\begin{array}{l}\text { Río Juruá, Brazil (Peres, 1997) } \\
\text { terra firme }\end{array}$ & $\begin{array}{l}4.7 \text { average of nine sites } \\
\text { (range } 1-8.4 \mathrm{ind} / \mathrm{km}^{2} \text { ) }\end{array}$ \\
\hline $\begin{array}{l}\text { El Tuparro (Defler, 1981) } \\
\text { gallery forest }\end{array}$ & $27-29$ \\
\hline $\begin{array}{l}\text { Manu, Perú (Terborgh, 1983; Janson \& } \\
\text { Emmons, 1990) tropical moist forest }\end{array}$ & 30 \\
\hline $\begin{array}{l}\text { La Barcareña (Defler, this study) } \\
\text { gallery forest }\end{array}$ & 42.5 \\
\hline $\begin{array}{l}\text { Río Juruá, Brazil (Peres, 1997) } \\
\text { Várzea }\end{array}$ & $\begin{array}{l}\text { 40.7 average of six sites } \\
\text { (range } 15.6-89.7 \text { ind. } / \mathrm{km}^{2} \text { ) }\end{array}$ \\
\hline $\begin{array}{l}\text { Hato Masagural, Estado de Guarico, } \\
\text { Venezuela (Crockett \& Eisenberg, } \\
\text { 1981) gallery forest }\end{array}$ & $\begin{array}{l}\text { 83-118 data from four } \\
\text { studies }\end{array}$ \\
\hline
\end{tabular}


The highest densities of Cebus apella were from La Barcareña gallery forest site, the highest densities of which this author has knowledge. Other calculated densities of this species (Caparú and Purité River) were much lower. Considering the very wide distribution of this species throughout the Amazon basin, it is of great ecological interest that we have not registered C. apella in the majority of the Colombian trapezium (the local name for that portion of the Colombian Amazon between the Putumayo river and the Amazon river) at any of our study sites (7-13). Where C. apella is absent, densities of $C$. albifrons are much higher than the densities of this species where it is syntopic with $C$. apella, suggesting some sort of density compensation (Peres \& Dolman, 2000). Like $C$. apella, the highest density of $C$. albifrons was also measured in the Colombian gallery forest (site 2). The pattern of dominance of $C$. apella when syntopic with C. albifrons also seems to be reflected in other Amazonian data sets (Peres, 1997; Endo et al., 2009; Palacios \& Peres, 2005; Haugaasen \& Peres, 2005, among others). High densities of Cebus in gallery forest suggest a preference for edge habitat with high densities of Cebus albifrons in the llanos and may also suggest a preference for drier, more deciduous forests than in many parts of the Amazon.

Saimiri was present at most Amazonian sites at low densities of 6-18 individuals $/ \mathrm{km}^{2}$, reaching 24.6 individuals $/ \mathrm{km}^{2}$ at a site close to the Amazon River in the south (site 10). This species' densities were also low in the igapó forest site 3 at Caparú.

Callicebus torquatus generally shows low densities for sites 4, 6, 7 and high densities in the gallery forest of El Tuparro. Why $C$. torquatus should show such high densities in a gallery forest in the Colombian Llanos is not clear, although fertility factors might have increased the preferred food available. Callicebus is notoriously patchy in distribution and censuses passing through habitat patches will register high densities (Defler, pers. obs.). These patches, separated by wide expanses of forest where Callicebus is absent, may be affected by fluvial and lacustrine forest, since all sites had populations of Callicebus close to the water in generally tall, well-stratified forest. In the gallery forest of Tapón of El Tuparro the habitat is probably more homogeneous, approximating a preferred habitat for the species throughout its length.

Pithecia monachus was present in four Amazonian sites south of the Caquetá River (sites 6-9) at moderate densities (4-14.5 individuals $/ \mathrm{km}^{2}$ ) and in clumped distributions. Like Callicebus torquatus, this species may be attracted to tall, well-stratified fluvial and lacustrine forest, since all sites had populations close to the water and they are frequently detected from boats. Their additional success in patches of vege- tation in fragmented regions suggests a certain tolerance for edge habiat [Defler, unpublished data].

Only The Puré (6) contained Saguinus fuscicollis at low densities $\left(8 \mathrm{ind} / \mathrm{km}^{2}\right)$, but three sites had Saguinus nigricollis with moderate densities (14-15 ind $\left./ \mathrm{km}^{2}\right)$ along the clearwater Purité River. Many Saguinus species seem to show higher densities around secondary vegetation (pers. obs. Defler, for Saguinus fuscus and S. inustus and S. nigricollis), perhaps because of fast-growing small, soft fruits and increased solar exposure, attracting many grazing insects (Defler, 2004, 2010), but this posited effect has not been reported or tested in the literature.

\section{Community biomass comparisons with the Duda River community}

Although the six sites in the eastern Colombian Amazon always had higher species richness than the western Amazonian Duda River community, total primate biomass on the Duda River, with an annual precipitation of $2600 \mathrm{~mm}$, was far greater than any that I surveyed. Stevenson (1996) calculated a biomass of $497.3 \mathrm{~kg} / \mathrm{km}^{2}$ for the six species of diurnal primates at his site, which included Lagothrix lugens, Ateles belzebuth and Alouatta seniculus - a syntopic array of three large species of considerable biomass, which this author has never personally observed in eastern Colombia. I observed somewhat comparable high biomass communities (with lower species richness) only in the Llanos with 387 and $370 \mathrm{~kg} / \mathrm{km}^{2}$ (due to high densities of Alouatta and Cebus spp.). Amazonian primate communities in this study varied between $86 \mathrm{~kg}-216.5 \mathrm{~kg}$ and averaged only $142.5 \mathrm{~kg}$ of primate biomass.

\section{Edaphic factors, precipitation and biomass densities}

The tropical moist forests in this comparative study experience precipitation between 3200-3950 mm per year. Consistently heavy rains leach soils of calcium, magnesium and potassium, causing a decrease in phosphorus availability and creating more acidic soil, all of which affect crop size and primary production (Defler \& Defler, 1996; Reed \& Fleagle, 1995). At higher primate biomass sites of La Barcareña and the Duda river, phosphorus levels are elevated, compared to measured sites in the eastern Colombian Amazon. I suggest this is the cause of reduced diversity and biomass in the eastern Colombian Amazon as discussed by Peres (2008).

\section{General community characteristics}

Based on information from a variety of field surveys cited above and sites in the eastern Colombian Amazon (as repor- 
ted in this study) some general observations can be made. A typically species-rich Amazonian community usually possesses the large sympatric frugivores Ateles and Lagothrix, two species of Saguinus (not so in the Duda river), two species of Callicebus and two species of Cebus (not in the peripheral Duda river). When C. albifrons and C. apella are syntopic, the biomass of $C$. apella is usually much higher than that of C. albifrons (this study). In eastern Colombia, species richness is moderate and the densities of each species are notably lower than in many communities studied south of the Amazon River, while in eastern Amazonian Colombia there is only one large frugivore species, one Saguinus and sometimes only one Cebus species. It is noteworthy that not only were biomass values very low in eastern Colombia but species richness is moderate as compared to primate communities further south of the Amazon river at the same latitudes. It would seem that some of the factors that affect community biomass also affect species richness as well, especially phosphorus levels, and I suggest that high precipitations (well over $2500 \mathrm{~mm}$ ) and soil impoverishment are the likely factors that suppress biomass and species richness.

\section{Acknowledgments}

The author's fieldwork was supported by Conservation International USA, Primate Action Fund, Conservación Internacional Colombia, the Margot Marsh Biodiversity Foundation, Colciencias (Colombia), National Geographic Society, the World Wildlife Fund (USA), the Wildlife Conservation Society, Fundación Natura (Colombia) and the Universidad Nacional de Colombia.

Thanks to Sara Bennett, volunteer assistants and the Colombian Park System for their support. I thank Mario Salazar for transportation to the northernmost site in the Colombian llanos and for gathering rainfall data for that site throughout various years. Thanks to Anthony Rylands, Brian Milton and three anonymous reviewers for critical comments on earlier versions that have contributed greatly to the clarity of this article. Aditionally thanks to Angela Maldonado and Thomas Lafon who worked with me on another earlier version of this manuscript, which was to have Maldonado as second author. Removal of Maldonado's data seemed to add coherence to the discussion and conclusions presented here.

\section{References}

Buckland, S.T., D.R. Anderson, K.P. Burnham, J. L. Laake, D.L. Borchers \& L. Thomas 2001. Introduction to Distance Sampling: Estimating Abundance of Biological Populations. Oxford, Oxford University Press.

Chapman, C.A. \& S.E. Russo 2007. Primate seed dispersal: Linking behavioural ecology and forest community structure. In: Campbell,
C.J., A.F. Fuentes, K.C. MacKinnon, M. Panger, and S. Bearder editors. Primates in Perspective. Oxford University Press, Oxford pp.510-525.

Correa, S.B. 2008. Fish assemblage structure is consistent through an annual hydrological cycle in habitats of a floodplain lake in the Colombian Amazon. Neotropical Icthyology 6(2):257-266.

Crockett, C. \& J.F. Eisenberg 1987. Howlers: Variations in group size and demography. In: B.B. Smuts, D.L. Cheney, R.M. Seyfarth, R.W. Wrangham and T.T. Struhsaker, editors. Primate Societies. Chicago, The University of Chicago Press. pp. 54-68.

Davis, W. 1996. One river. Simon \& Schuster, New York.

Defler, T.R. 1983. Observaciones sobre los primates del bajo río MiritíParaná, Amazonas, Colombia. Lozania 46:1-13.

Defler, T.R. 1989. Recorridos y uso del espacio en un grupo de Lagothrix lagothricha (mono lanudo o churuco) en la Amazonia colombiana. Trianea (Acta Cientifica y Tecnológica, INDERENA) 3: 183-205.

Defler, T.R. 2001. Cacajao melanocephalus ouakary densities on the lower Apaporis river, Colombian Amazon. Primate Report 61: 31-36.

Defler, T.R. 2003. Densidades de especies y organización espacial de una comunidad de primates: la Estación Biológica Caparú, Vaupés, Colombia. In: V. Pereira-Bengoa, V, F. Nassar-Montoya and A. Savage, editors. Primatología del Nuevo Mundo: Biología, Medicina, Manejo y Conservación. Centro de Primatología Araguatos, Bogotá. pp. 23-39.

Defler, T.R. 2010. Historia natural de primates colombianos. Universidad Nacional de Colombia, Bogotá.

Defler, T.R. \& D. Pintor 1985. Censusing primates in a forest of known primate density. International Journal of Primatology 6(3): 243-260.

Defler, T.R. \& S.B. Defler 1996. The diet of a group of woolly monkeys (Lagothrix lagothricha lagothricha) in southeastern Colombia. International Journal of Primatology 17(2):161-190

Dietz J., L. Dietz \& E. Nagatata 1994. The effective use of flagship species for conservation of biodiversity: the example of lion tamarins in Brazil. In: P. Olney, G. Mace and A. Feistner, editors. Creative conservation: interactive management of wild and captive animals . Chapman \& Hall, London. pp. 32-49.

Emmons, L.H. 1984. Geographic variation in densities and diversities of non-flying mammals in Amazonia. Biotropica 16(3): 210-222.

Endo, W., C.A. Peres, E. Salas, S. Mori, J. L. Sanchez-Veja, G. H. Shepard, V. Pacheco \& D. W. Yu 2009. Game vertebrate densities in hunted and nonhunted forest sites in Manu National Park, Peru. Biotropica 42: 251-261.

Garber P.A. \& J.E. Lambert 1998. Primates as seed dispersers: Ecological processes and directions for future research. American Journal of Primatology. 45(1): 3-8

Gentry, A.H. 1982. Patterns of neotropical plant species diversity. In: M.K. Hecht, B. Wallace, and G.T. Prance, editors. Evolutionary Biology 15:1-84. Plenum, New York.

Gentry, A.H. 1989. Diversidad florística y fitogeográfica de la Amazonia. In: J.I. Hernández Camacho, J.V. Rodríguez, H. Chiriví and H.P. Sánchez, editors. Investigación y Manejo de la Amazonia, Bogotá, INDERENA, Bogotá, pp.65-70.

Goulding, M., R. Barthem \& E. Ferreira 2003. The Smithsonian Atlas of the Amazon. Smithsonian Institution: Washington, D.C.

Haugaasen, T. \& C.A. Peres. 2005. Primate assemblage structure in Amazonian flooded and unflooded forests. American Journal of Primatology 67:243-258.

Hirabuki, Y. \& K. Izawa 1990. Chemical properties of soils eaten by wild red howler monkeys (Alouatta seniculus): A preliminary study. Field Studies of New World Monkeys, La Macarena, Colombia 3:25-28. 
Hoorn, C. , M. Roddaz, R. Dino, E. Soares, C. Uba, D. Ochoa-Lozano \& R. Mapes. 2010. The Amazonian cratón and its influence on past fluvial systems (Mesozoic-Cenozoic, Amazonia). In: C. Hoorn and F. Wesselingh, editors. Amazonia, landscape and species evolution: A look into the past. John Wiley \& Sons, New York. pp. 103-122.

Howe, H.F. \& J. Smallwood 1982. Ecology of seed dispersal. Annual Review of Ecology and Systematics 13: 201-228.

Janson, C.H. \& C.A. Chapman 1999. Resources and primate community structure. In: J.G. Fleagle, C.H. Janson and K.E. Reed, editors. Primate Communities, Cambridge, Cambridge University Press. pp.237267.

Janson, C.H. \& L.H. Emmons, LH (1990). Ecological structure of the nonflying mammal community at Cocha Cashu Biological Station, Manu National Park, Peru. In: A.H. Gentry, editor. Four Neotropical Rainforests. New Haven, Yale University Press. pp.314-338.

Jordan, C.F. 1985. Nutrient Cycling in Tropical Forest Ecosystems: Principles and Their Application in Management and Conservation. John Wiley \& Son, New York. 190 pp.

Junk, W. \& K. Furch 1985. Chapter 1: The physical and chemical properties of Amazonian waters and their relationship with the biota. In: G.T. Prance and T.E. Lovejoy, editors. Key Environments: Amazonia. Pergamon Press, Oxford. pp. 3-17.

Kay, R.F., R.H. Madden, C. Van Schaik \& D. Higdon 1997. Primate species richness is determined by plant productivity: implications for conservation. Proceedings of the National. Academy of Science USA 94:13023-13027.

Maldonado, A. 2012. The role of woolly monkeys as a flagship species for conservation in the Colombian Amazon (work in progress). (downloaded 14 Julio 2012. http://www.ruffordsmallgrants.org/files/ 96.07.04\%20Dec\%20update.pdf

NRC (National Research Council) 1981. Techniques for the Study of Primate Population Ecology. Washington, D.C., National Academy Press.

Palacios, E. \& C.A. Peres 2005. Primate population densities in three nutrient-poor Amazonian terra firme forests of south-eastern Colombia. Folia Primat.ologica 76:3,135-145.

Peres, C. A. 1993. Structure and spatial organization of an Amazonian terra firme forest primate community. Journal of Tropical Ecolology 9: $259-276$.

Peres, C.A. 1997. Primate community structure at twenty western Amazonian flooded and unflooded forests. Journal of Tropical Ecolology 13: 381-405.

Peres, C.A. 1999. General guidelines for standardizing line-transect surveys of tropical forest primates. Neotropical. Primates 7(1): 11-16.

Peres, C.A. 2008. Soil fertility and arboreal mammal biomass in tropical forests. In: W. Carson and S. Snitzer, editors. Tropical Forest Community Ecology, Wiley, New York. pp. 349-364.

Peres, C.A. \& C.H. Janson 1999. Species coexistence, distribution, and environmental determinants of neotropical primate richness: A community-level zoogeographic analysis. In: J.G. Fleagle, C.H. Janson,
K.E. Reed, editors. Primate Communities. Cambridge University Press, Cambridge. pp.55-74

Peres, C.A. \& P.M. Dolman (2000). Density compensation in neotropical primate communities: Evidence from 56 hunted and nonhunted Amazonian forests of varying productivity. Oecologia 122(2):175-189.

Peres, C. A. \& E. Palacios 2007. Basin-wide effects of game harvest on vertebrate population densities in Amazonian forests: implications for animal-mediated seed dispersal. Biotropica 39(3):304-315.

Pires, J.M. \& G.R. Prance 1985. The vegetation types of the Brazilian Amazon. In: G.T. Prance and T. E. Lovejoy, editors. Key Environments: Amazonia. Pergamon Press, New York. Pp. 109-145.

Puertas, P. \& R.E. Bodmer 1993. Conservation of a high diversity primate assemblage. Biodiversity Conservation 2: 586-593.

Reed, K.E. \& J.G. Fleagle 1995. Geographic and climatic control of primate diversity. Proceedings of the National Academy of Science, USA 92: 7874-7876.

Stevenson, P.R. 1996. Censos diurnos de mamíferos y algunas aves de gran tamaño en el Parque Nacional Natural Tinigua, Colombia. Universitas Scientiarum 3(1-2): 67-81.

Stevenson, P.R. \& A. Pilar Medina 2003. Dispersión de semillas por micos churucos (Lagothrix lagothricha) en el Parque Nacional Tinigua, Colombia. In: V. Pereira-Bengoa, F. Nassar-Montoya \& A. Savage, editors. Primatología del Nuevo Mundo: Biología, Medicina, Manejo y Conservación. Centro de Primatología Araguatos, Bogotá. pp. 122-135.

Stevenson, P.R., M. Pineda \& T. Samper 2002. Effects of seed dispersal by three ateline monkey species on seed germination at Tinigua National Park, Colombia. International Journal of Primatology 23(6):1187-1204.

Terborgh, J. 1983. Five New World Primates: a Study in Comparative Ecology. Princeton, Princeton University Press.

Terborgh, J. 1992. Diversity and the Tropical Rain Forest. W. H. Freeman and Company, New York.

Thomas, L., J.L. Laake, S. Strindberg, F.F.C. Marques, S.T. Buckland, D.L. Borchers, D.R. Anderson, K.P. Burnham, S.L. Hedley, J.H. Pollard, J.R.B. Bishop \& T.A. Marques 2005. Distance 5.0. Beta 5. Research Unit for Wildlife Population Assessment, University of St. Andrews, UK. http://www.ruwpa.st-and.ac.uk/distance/

Umaña, M.N., P. Stevenson, A.B. Hurtado, D. Correa \& I. Medina 2011. Dispersal syndromes among three landscape units in Colombian lowland Amazonia. The International Journal of Plant Reproductive Biology 3(2):155-159.

Voss, R.S. \& L.H. Emmons 1996. Mammalian diversity in neotropical lowland rainforests: a preliminary assessment. Bulletin of the American Museum of Natural History 230:1-115.

Recibido: 3 de mayo de 2013

Aceptado para su publicación: 4 de junio de 2013 